\title{
The Impact of Dietary Protein in Complementary Foods on Infant Growth and Body Composition in a Population Facing the Double Burden of Malnutrition: Protocol for a Multicenter, Prospective Cohort Study
}

Kulnipa Kittisakmontri ${ }^{1,2}$, MD; Julie Lanigan ${ }^{1}$, PhD; Jonathan C K Wells ${ }^{1}$, PhD; Mary Fewtrell ${ }^{1}$, MD

${ }^{1}$ Childhood Nutrition Research Centre, Population Policy and Practice Research and Teaching Department, Great Ormond Street Institute of Child Health, University College London, London, United Kingdom

${ }^{2}$ Department of Pediatrics, Faculty of Medicine, Chiang Mai University, Chiang Mai, Thailand

\section{Corresponding Author:}

Kulnipa Kittisakmontri, MD

Childhood Nutrition Research Centre, Population Policy and Practice Research and Teaching Department

Great Ormond Street Institute of Child Health

University College London

30 Guilford Street, Holborn

London, WC1N 1EH

United Kingdom

Phone: 4407706558053

Email: kulnipa.kittisakmontri.16@ucl.ac.uk

\begin{abstract}
Background: Protein is an essential macronutrient with an important role during complementary feeding. Low protein intake contributes to undernutrition while high intake, especially from animal sources, may increase obesity risk. However, the influences of different protein sources (dairy, meat, and plants) on growth, and underlying mechanisms for these effects, are poorly understood. Animal-sourced foods provide both high-quality protein and iron and are recommended to improve iron status. However, it is unclear whether current dietary recommendations are adequate to support healthy growth and optimize iron status. These issues are of particular concern in countries facing the double burden of malnutrition, the coexistence of all forms of malnutrition. More evidence is needed to develop appropriate recommendations for these countries.
\end{abstract}

Objective: This study will investigate associations between protein intake during complementary feeding and growth, body composition, and iron status of infants in Thailand, a country facing the double burden of malnutrition. The study will also explore how different protein sources influence growth via the growth hormone-insulin-like growth factor I (IGF-1) axis and plasma amino acids.

Methods: A multicenter cohort study will be conducted in Chiang Mai, Thailand, in 150 healthy term infants aged 4-6 months with birth weight $\geq 2500 \mathrm{~g}$. Demographic data, dietary intake, and anthropometry will be collected at 6, 9, and 12 months. Dietary intake will be assessed using 24-hour dietary recalls, 3-day food records, and food frequency questionnaires. Blood samples for iron status, growth hormone, IGF-1, insulin-like growth factor-binding protein III (IGFBP-3), and plasma amino acids and urine samples for body composition analysis using stable isotope dilution will be obtained at 12 months.

Results: The recruitment of study participants and data collection was undertaken from June 2018 to May 2019. Data and laboratory analyses are ongoing and are expected to be completed by December 2020. A total of 150 participants were enrolled, and 146 completed the study. We hypothesized that protein intake from animal-sourced foods in recommended quantities could support normal weight and length gain and lower the risk of undernutrition associated with similar amounts of plant-based protein. However, higher protein intake, especially from milk protein, may be linked to increased body fat via plasma amino acids and the growth hormone-IGF axis.

Conclusions: The results of this study will provide data on current complementary feeding practices, focusing on protein and iron intake in Thai infants. This information, combined with data on associations with infant growth and iron status, will help inform complementary feeding recommendations for this population and may be found relevant to other settings experiencing the double burden of malnutrition. 
International Registered Report Identifier (IRRID)： DERR1-10.2196/18112

(JMIR Res Protoc 2020;9(9):e18112) doi: 10.2196/18112

\section{KEYWORDS}

complementary feeding; protein intake; double burden of malnutrition; infant growth; body composition

\section{Introduction}

In 2016, while 52 and 155 million children around the globe were suffering from wasting and stunting, 41 million children under the age of 5 years were overweight or obese [1]. Therefore, the United Nations General Assembly launched a new policy, the United Nations Decade of Action on Nutrition from 2016 to 2025 . The policy aims to end hunger and eradicate all forms of malnutrition worldwide [1]. In this proclamation, the double burden of malnutrition, the coexistence of undernutrition, overweight, obesity, and diet-related noncommunicable diseases are highlighted as an emerging public health problem in many countries experiencing socioeconomic transition. In order to achieve the goals of the proclamation, early life nutrition, especially during the first 1000 days of life, has been identified as one of the primary targets of intervention [2].

Along with optimal maternal nutrition and exclusive breastfeeding until 6 months of age, complementary feeding plays a pivotal role in early life nutrition from the age of 6 to 24 months. This period is also the most challenging, as a systematic review indicated that no single intervention can optimize growth outcomes for infants living in different circumstances with variations in the availability of micronutrient-rich foods, degree of household food insecurity, and traditional complementary feeding practices [3]. Among various topics related to complementary feeding, dietary protein is interesting as it is linked to all forms of malnutrition.

Protein is an essential macronutrient needed to build organ systems and body structures and mediates many physiological functions throughout life. For infants and young children, protein requirements per kg body weight are higher than any other age groups due to their rapid growth [4]. In addition, the proportion of energy from protein abruptly changes from 5\% to around $15 \%$ of total energy intake when breastfed infants are introduced to complementary foods [5]. According to current evidence, insufficient protein intake during complementary feeding can contribute to undernutrition [6-8], whereas too much may increase the risk of overweight and obesity in later life [9-13].

Nevertheless, it is not only the amount of dietary protein that matters but also the source. Dietary protein comes from either animals or plants. Some studies have shown a link between protein sources and growth via plasma amino acids and the growth hormone-insulin-like growth factor I (IGF-1) axis. Semba et al demonstrated that stunted children had lower levels of plasma essential amino acids [14]. In contrast, a multicenter randomized controlled trial in 5 European countries showed that plasma Leucine and IGF-1 were positively associated with body mass index $\mathrm{z}$-score (BMIZ) in infants who received high protein intake from infant formula [15]. These findings have two important implications. First, protein from animal-sourced foods such as milk, meat, and eggs provides all essential amino acids, while plant-based proteins (cereals, legumes, vegetables) usually lack one or two essential amino acids. Thus, it can be assumed that the effect of dietary protein on growth is more closely related to protein source than quantity. Second, as the proportion of leucine in the amino acid content of whey is higher in milk than that in meat (14\% vs $8 \%$, respectively) [16], protein intake from nondairy animal-sourced foods may not have the same influence on BMIZ as similar intake from milk. However, few studies have measured body composition as it relates to the intake of different protein sources.

Most evidence comes from two separate paradigms. The first has focused on lower- and middle-income countries where the researchers try to encourage higher protein intake in terms of both quantity and quality to overcome undernutrition, while the second paradigm is emerging in higher-income settings where researchers are aiming to prevent obesity by reducing the protein intake of infants and young children. As a result of these separate approaches, it is difficult to define guidelines for countries that are now facing the double burden of malnutrition, the majority of which are low- to middle-income countries.

Thailand is a country facing the double burden of malnutrition. The latest national and international surveys demonstrate a slowly declining percentage of childhood stunting, a high prevalence of iron deficiency, and rapidly increasing proportions of overweight, obesity, and diet-related noncommunicable diseases at a population level [17-19]. However, there have been no recent studies on protein intake among Thai infants. Although the latest Thai dietary reference intakes recommend a protein intake of $1.56 \mathrm{~g} / \mathrm{kg} /$ day for Thai infants aged 6-11 months [20], there have been no clinical studies to support the adequacy of this recommendation in Thai infants as the recommendation is adapted from international guidelines [4].

\section{Aims and Hypotheses}

We aim to understand the impact of dietary protein in early life using a holistic approach. This study will fill some of the knowledge gaps related to underlying mechanisms through the following objectives and hypotheses:

1. We will investigate the associations between the amounts and sources of dietary protein typically provided to Thai infants aged 6 to 12 months and changes in growth, including weight-for-age z-score (WAZ), weight-for-length z-score (WLZ), length-for-age z-score (LAZ), and BMIZ over 6-12 months. We will test the hypothesis that protein intake from animal-sourced foods in recommended quantities can support normal weight and length gain and reduce the risk of undernutrition associated with similar amounts of plant-based protein. 
2. We will investigate the associations between the amounts and sources of dietary protein typically provided to Thai infants aged 6 to 12 months and body composition at 12 months of age. We will test the hypothesis that a higher intake of protein from animal-sourced foods, especially dairy protein, is associated with an increased proportion of body fat during infancy.

3. We will investigate the associations between complementary foods that provide different amounts of protein from animal-sourced foods and plant-based diets typically provided to Thai infants aged 6 to 12 months with iron status at 12 months of age. We will test the hypothesis that the timely introduction of protein from animal-sourced foods, especially red meat in the recommended amount, is associated with improved iron status and lower risk of iron deficiency anemia, without increasing the risk of overweight/obesity.

4. We will investigate the possible mechanisms linking dietary protein and growth in early life through metabolomic processes. We will test the hypothesis that high protein intake from animal-sourced foods is associated with increased plasma essential amino acids, which may be correlated with concentrations of growth hormone, IGF-1, and IGFBP-3.

\section{Methods}

\section{Study Design and Approval}

\section{Study Design}

This protocol is for a multicenter, prospective cohort study.

Textbox 1. Definitions.

Complementary feeding is all solid and liquid foods other than breast milk or infant and follow-on formula, as suggested by the European Food Safety Authority (EFSA) [21] and the position papers from the European Society for Pediatric Gastroenterology Hepatology and Nutrition [22].

Stunting is defined as LAZ $<2$ SD below the median of the WHO growth standards for children aged under 5 years [23].

Wasting is defined as WLZ $<2$ SD below the median of the WHO child growth standards for children aged under 5 years [23].

Underweight is defined as WAZ is $<2 \mathrm{SD}$ below the median of the WHO child growth standards for children aged under 5 years [23].

Overweight is defined as WLZ > 2 SD above the median of the WHO child growth standards for children aged under 5 years [24].

Obesity is defined as WLZ > 3 SD above the median of the WHO child growth standards for children aged under 5 years [24].

Iron deficiency is defined by at least one of the following serum ferritin less than $12 \mu \mathrm{g} / \mathrm{L}$ (if erythrocyte sedimentation rate, ESR $\leq 10 \mathrm{~mm} / \mathrm{h}$ ) or serum ferritin less than $30 \mu \mathrm{g} / \mathrm{L}$ (if ESR $>10 \mathrm{~mm} / \mathrm{h}$ ) or serum transferrin saturation less than $16 \%$ [25].

Iron deficiency anemia is defined as iron deficiency plus hemoglobin $<11.0 \mathrm{~g} / \mathrm{dL}$ [25].

Exclusive breastfeeding means the infant receives only breast milk without anything else except for water and necessary medication.

Predominant breastfeeding means that breast milk is more than $50 \%$ of daily milk intake after 6 months of age.

Predominant formula feeding means that infant or follow-on formula provides more than $50 \%$ of daily milk intake and for a longer period than breastfeeding.

Animal-sourced food is defined as any food that is edible and originates from animals such as milk, dairy products, meat (ie, beef, pork, poultry), processed meats, fishes, insects, and eggs.

Plant-based protein is defined as dietary proteins that are edible and originate from plants such as cereals, lentils, legumes, nuts, and vegetables.

The primary caregiver is defined as the person who spends the most time looking after the infant on a daily basis. 


\section{Study Population}

\section{Inclusion Criteria}

Eligible infants are full-term (gestational age $\geq 37$ weeks), healthy, singleton infants aged 4-6 months whose birth weight was $\geq 2500 \mathrm{~g}$.

\section{Exclusion Criteria}

Infants with any underlying or chronic diseases, those with a known case of, or recovery from, protein-energy malnutrition, and infants regularly receiving medication except mineral and vitamin supplementation will be excluded.

\section{Participant Selection and Recruitment}

Parents or caregivers of infants aged 4-6 months who are eligible for the study will be approached by a researcher when they routinely visit the well-baby clinic and asked if they are interested in taking part in the study. The researcher will give the parent an information sheet and answer all queries on a case by case basis. If they consider participating, contact details will be obtained. After 48 hours, the researcher will call the parents to ask if they wish to take part and, if they agree, the first appointment will be scheduled. At the first visit, informed consent will be signed by the parent or legal guardian who is the primary caregiver of the participant.

\section{Data Collection}

There are 3 visits at the well-baby clinic for each participant when they are 6,9, and 12 months of age (Table 1).

Table 1. Data and collection of biological samples.

\begin{tabular}{|c|c|c|c|}
\hline Data collection & First visit, age 6 months & Second visit, age 9 months & Third visit, age 12 months \\
\hline Demographic data & $\begin{array}{l}\text { - } \quad \text { Family type, family income (month- } \\
\text { ly), primary caregiver } \\
\text { - } \quad \text { Parental education and occupation } \\
\text { - } \quad \text { Parental body weight and height } \\
\text { - } \quad \begin{array}{l}\text { Prenatal screening and problems } \\
\text { - }\end{array} \text { Mode of delivery, gestational age at } \\
\text { birth, birth weight, length, and head } \\
\text { circumference } \\
\text { - Postnatal problems (eg, neonatal } \\
\text { jaundice) }\end{array}$ & - $\quad \mathrm{N} / \mathrm{A}^{\mathrm{a}}$ & - N/A \\
\hline
\end{tabular}

Milk feeding

Dietary intake
- Type of milk feeding, duration of exclusive breastfeeding

- Age of first introduction of complementary feeding, type of first complementary feeding, age of introducing each type of diet (cereal, meat, egg, milk)

- 24-hour dietary recall

- Food Frequency and Baby Eating Behavior Questionnaire
- Type of milk feeding, duration of breastfeeding/using breast milk

- Age of introducing each type of diet

- 24-hour dietary recall

- 3-day food record

- Food Frequency and Baby Eating Behavior Questionnaire
Type of milk feeding, duration of breastfeeding/using breast milk

- Age of introducing each type of diet

- 24-hour dietary recall

- 3-day food record

- Food Frequency and Baby Eating Behavior Questionnaire

\begin{abstract}
Anthropometric measurements

- Bodyweight, length, head circumference, mid-upper arm circumference
\end{abstract}

- Bodyweight, length, head circumference, mid-upper arm circumference

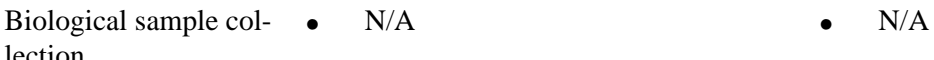
lection
- Bodyweight, length, head circumference, mid-upper arm circumference

- Blood sample: $5 \mathrm{ml}$ venous blood

- Body composition: $1.5 \mathrm{~mL}$ urine $\times 3$ samples, before and after dosing with Deuterium oxide

- Feeding problems, acute illness

${ }^{\mathrm{a} N} / \mathrm{A}$ : not applicable.

\section{Biological Sample Collection, Preparation, and Storage Blood Samples}

At 12 months of age, a venous blood sample will be obtained by experienced nurses or health professionals. Five milliliters of venous blood will be separated into 4 collecting tubes; 1 EDTA tube for ESR and plasma amino acids, 1 EDTA microtainer for complete blood count (CBC), 1 clotted blood tube for growth hormone, IGF-1, IGFBP-3, and 1 heparinized microtainer for serum ferritin, serum iron, and serum total iron-binding capacity. The blood samples for CBC, ESR, serum ferritin, serum iron, and total iron-binding capacity will be analyzed on the day of blood collection. The rest of the blood samples for growth hormone, IGF-1, IGF-binding protein 3 (IGFBP-3), and plasma amino acid analysis will be centrifuged 
and aliquoted into cryovials within the same day and stored at $-80^{\circ} \mathrm{C}$ until analysis.

\section{Urine Samples}

Infant body composition will be measured by the isotope dilution technique using deuterium oxide $\left({ }^{2} \mathrm{H}_{2} \mathrm{O}\right)$. At 12 months of age, the dose of deuterium oxide calculated according to infant body weight $\left(0.1 \mathrm{~g}\right.$ per $\mathrm{kg}{ }^{2} \mathrm{H}_{2} \mathrm{O}$ body weight $)$ will be prepared as a solution (in water, juice, or milk) and orally administered to infants during their final visit. Urine samples will be obtained before dosing and after dosing at 6 and 24 hours. Urine samples will be stored at $-80^{\circ} \mathrm{C}$ until analysis.

\section{Study Outcomes}

\section{Primary Outcome}

The primary outcome measure will be the conditional change of growth parameters (WAZ, WLZ, LAZ) from 6-12 months of age.

\section{Secondary Outcomes}

Secondary outcome measures will be (1) the conditional change of BMIZ from 6-12 months of age, (2) anthropometric measurements at 12 months of age, (3) infant body composition at 12 months of age, (4) iron status including $\mathrm{CBC}$, serum ferritin, SI and total iron-binding capacity at 12 months of age, (5) growth-related hormones (growth hormone, IGF-1, IGFBP-3) at 12 months of age, and (6) plasma amino acids at 12 months of age.

\section{Outcome Measures}

\section{Energy and Nutrient Intake}

Dietary data will be collected using 24-hour dietary recalls and the Food Frequency Questionnaire at 6, 9, and 12 months and 3-day food records at 9 and 12 months. All dietary data will be converted to energy and nutrient intake (ie, carbohydrate, fat, protein, calcium, phosphorus, iron, zinc, vitamin B1, vitamin B2, vitamin C, and vitamin A) by using the Institute of Nutrition Mahidol University Calculation program version 4.0 developed by the Institute of Nutrition, Mahidol University, Bangkok, Thailand [26]. This program reports total protein and iron intake from both animal and plant sources. Breastfeeding will be recorded as frequency and duration (minutes per meal) each day, then the volume of breast milk will be estimated using the average amount from two algorithms [27,28].

\section{Anthropometric Assessment}

Bodyweight will be measured using calibrated electronic scales accurate to $0.01 \mathrm{~kg}$ and recumbent length using a standard wood board accurate to $0.1 \mathrm{~cm}$. The SD z-scores for weight-for-age, length-for-age, weight-for-length, and BMI will be calculated using WHO software (WHO Anthro version 3.2.2) based on the 2007 WHO Growth Standard [29]. Although the WHO recommends weight-for-length to be used to determine wasting and overweight for children aged $<2$ years, a recent study showed that infant BMI had a higher positive predictive value than weight-for-length for childhood obesity [30].Therefore, the present study will measure both indices.

\section{Dietary Data Collection Tools}

The format of the 24-hour dietary recalls and 3-day food records have been adapted from Lanigan et al [27] and translated into the Thai language by the researcher who is a Thai native speaker. The semi-quantitative Food Frequency Questionnaire was developed with information on food items consumed by Thai infants and toddlers aged 0-3 years relating to the food consumption data of Thailand 2016 [31]. The Food Frequency Questionnaire contains 130 food items. Appetite traits will be evaluated by the Baby Eating Behavior Questionnaire, which was developed by Llewellyn et al from the Gemini birth cohort [32].

\section{Laboratory Analyses}

\section{Infant Body Composition}

Urine samples will be measured by isotope-ratio mass spectrometry (Gasbench-Delta XP system, Thermo Fisher Scientific, Bremen).

\section{Iron Status}

CBC will be analyzed by using an automated hematological analyzer (Sysmex XN 9103, Sysmex UK). An automated system will be used for the direct determination of ESR (VES-MATIC cube 30, DIESSE Diagnostica Senese). Serum ferritin, serum iron, and total iron-binding capacity will be analyzed by using a chemiluminescent method (Cobas modular analyzer, Roche Diagnostics, F Hoffmann-La Roche, Germany).

\section{Growth-Related Hormones}

Growth hormone, IGF-1, and IGFBP-3 will be analyzed by enzyme-linked immunosorbent assay (IMMULITE 2000, Siemens Healthcare Diagnostics Products).

\section{Plasma Amino Acids}

Twenty plasma amino acids will be analyzed by using the high-performance liquid chromatography (Biochrom30 amino acid analyzer, Biochrom).

\section{Statistical Analysis}

There are two main parts of the statistical analysis. First, we will summarize the population characteristics of milk feeding, complementary feeding, and prevalence of undernutrition, overweight/obesity, and iron deficiency. Second, we will examine the associations between protein intake and source during complementary feeding and the outcomes specified in the objectives and hypotheses. All statistical tests will be considered significant when the $P$ value is $<.05$ or $95 \%$ CIs of odds ratios do not include 1.

Descriptive data will be presented as mean (SD), median with interquartile range, or percentages depending on data type and distribution. These data will include demographic characteristics of infants and families, breastfeeding rate, age of the first introduction of complementary feeding, details of complementary feeding and energy/nutrient intake at each time point, average growth parameters at each time point, growth trajectory, and the prevalence of malnutrition (including wasting, stunting, overweight/ obesity, iron deficiency, iron deficiency anemia). 
Protein intake at each time point, both total and separated by dietary source (ie, dairy protein, nondiary animal-based protein, and plant-based protein), will be considered as primary predictors to examine associations between protein intake and outcomes. To investigate associations between those predictors and continuous outcomes such as growth z-scores, percentage of body fat/fat-free mass, and blood parameters, we will use linear regression and correlation models (Pearson or Spearman correlation) for either univariate or multivariate analysis. For multivariate analysis, covariates will be selected for each of the dependent outcomes from previous research publications and our univariate analyses. Additionally, we intend to apply the directed acyclic graphs identifying covariates to reduce confounders [33]. If the dependent outcomes are categorical data such as nutritional status or iron status, binary or logistic regression analysis will be used as the main models.

The study aims to reduce the bias of baseline body size of individual infants on growth outcomes by using conditional growth. This method captures how an individual child deviates from the average growth trajectory in the population, taking into account overall regression to the mean, and expresses

Textbox 2. Sample size calculation. growth acceleration or deceleration in an individual relative to this population growth pattern. For example, if the conditional weight $\mathrm{z}$-score is positive, we can interpret that the infant has shown more rapid weight gain than others in the population who had the same baseline size [34]. Therefore, the conditional change in growth parameters from 6 to 12 months will be calculated using linear regression of weight/length z-scores at 12 months on baseline values at 6 months. Residuals from the model represent the difference between observed and predicted growth over this period.

We will use data from the standard recommendations, previous research, and our own data to determine the most appropriate cut-offs for low or high protein intake. We will then compare the outcomes between these groups.

\section{Sample Size Calculation}

We used the two-different means formulae [35] to calculate the sample size required to detect a $0.5 \mathrm{SD}$ difference in growth parameters (WAZ, WLZ, and LAZ) between infants who receive red meat frequently and less frequently from 6-12 months of age (Textbox 2).

- Mean difference 0.5 SD

- SD 1.0 (adopted from Olaya G et al [36])

- $\quad$ Power $80 \%$, significance level .05

- Sample size: 126 participants

- With surplus $15 \%$ drop out rate, the final number is 148 participants

\section{Results}

Recruitment commenced in June 2018 and was completed in October 2018. Data collection was completed in May 2019. Laboratory analyses are ongoing and are expected to be complete by December 2020. Initially, 150 infants were enrolled, and only $4(3 \%)$ had dropped out at the end of the data collection period. The results of this study will be presented and disseminated through peer-reviewed journals and academic conferences.

\section{Discussion}

Thailand has highlighted early life nutrition as a window of opportunity to overcome the double burden of malnutrition [37]. Several campaigns from the Thai government have been launched to improve maternal and infant nutrition. Examples include a program that encouraged supplementation of Triferdine, which consists of iron, iodine, and folic to women of child-bearing age, promotion of exclusive breastfeeding until 6 months of age as well as iron supplementation of infants and young children aged 6 months to 2 years [38]. However, there is no specific campaign related to complementary feeding and, to the best of our knowledge, no recent studies in this field.

Although recommendations should ideally be based on experimental data, the lack of recent data on dietary protein intake and growth outcomes in Thai infants precluded the development of a practical intervention that could be tested in a randomized controlled trial in this population. To address this issue, we decided to adopt a sequential approach in 3 consecutive studies, beginning with a descriptive study to gather information on the attitudes, knowledge, and practices related to complementary feeding in Thai families. This study provided a clearer picture of complementary feeding among Thai parents and highlighted interesting findings that were used in the design of the current prospective cohort study [39]. For example, rice porridge and mashed banana were the most common first foods for Thai infants with or without a small amount of egg yolk. Some Thai parents delayed providing animal-sourced foods to their children and had concerns that such foods were difficult to digest and had high allergenicity compared with plant-based proteins.

The second phase of our research consists of the observational study described here, incorporating the findings of our previous study. The aim is to investigate the intake of different protein sources during complementary feeding and associations between protein intake and growth outcomes, body composition and iron status in the same population, as well as to investigate possible mechanisms related to those associations. The results of this study may be used to plan the third phase of our research, testing an intervention to improve growth and iron status in this infant population. 


\section{Acknowledgments}

This cohort study is funded by the Childhood Nutrition Research Centre, UCL Great Ormond Street Institute of Child Health. The authors thank Chiang Mai Health-Promoting Hospital, Chomthong Hospital, and Chiang Mai University Hospital for allowing us to conduct this cohort study in their well-baby clinics. We also thank the nurses and health professionals who are assisting with recruitment and Associate Professor Orawan Louthrenoo, the Head of the Department of Pediatrics, Faculty of Medicine, Chiang Mai University, who facilitated the research in Thailand.

\section{Authors' Contributions}

$\mathrm{KK}, \mathrm{MF}$, and JL were responsible for identifying the research questions, forming the hypotheses, and planning the study protocol. JW provided advice on technique and sample preparation for body composition analysis. KK wrote the manuscript with input from all coauthors. All authors read and approved the final manuscript.

\section{Conflicts of Interest}

None declared.

\section{References}

1. World Health Organization. The double burden of malnutrition Policy brief. Geneva: World Health Organization; 2017. URL: https://apps.who.int/iris/rest/bitstreams/1084411/retrieve [accessed 2020-09-06]

2. World Health Organization. Double-duty actions for nutrition Policy brief. Geneva: World Health Organization; 2017. URL: https://www.who.int/publications/i/item/WHO-NMH-NHD-17.2 [accessed 2019-12-01]

3. Dewey KG, Adu-Afarwuah S. Systematic review of the efficacy and effectiveness of complementary feeding interventions in developing countries. Matern Child Nutr 2008 Apr;4 Suppl 1:24-85 [FREE Full text] [doi: 10.1111/j.1740-8709.2007.00124.x] [Medline: 18289157]

4. WHO/FAO/UNU. Protein and amino acid requirements in human nutrition. Report of a joint WHO/FAO/UNU Expert Consultation. WHO Technical Report Series 935. Geneva: World Health Organization; 2007. URL: https://www.who.int/ nutrition/publications/nutrientrequirements/WHO TRS 935/en/ [accessed 2019-12-01]

5. Michaelsen KF, Grummer-Strawn L, Bégin F. Emerging issues in complementary feeding: Global aspects. Matern Child Nutr 2017 Oct;13 Suppl 2. [doi: 10.1111/mcn.12444] [Medline: 29032617]

6. Millward DJ. Nutrition, infection and stunting: the roles of deficiencies of individual nutrients and foods, and of inflammation, as determinants of reduced linear growth of children. Nutr Res Rev 2017 Jun;30(1):50-72. [doi: 10.1017/S0954422416000238] [Medline: 28112064]

7. Arsenault JE, Brown KH. Effects of protein or amino-acid supplementation on the physical growth of young children in low-income countries. Nutr Rev 2017 Sep 01;75(9):699-717 [FREE Full text] [doi: 10.1093/nutrit/nux027] [Medline: 28938793]

8. Semba RD. The Rise and Fall of Protein Malnutrition in Global Health. Ann Nutr Metab 2016;69(2):79-88 [FREE Full text] [doi: 10.1159/000449175] [Medline: 27576545]

9. Günther ALB, Remer T, Kroke A, Buyken AE. Early protein intake and later obesity risk: which protein sources at which time points throughout infancy and childhood are important for body mass index and body fat percentage at $7 \mathrm{y}$ of age? Am J Clin Nutr 2007 Dec;86(6):1765-1772. [doi: 10.1093/ajcn/86.5.1765] [Medline: 18065597]

10. Thorisdottir B, Gunnarsdottir I, Palsson GI, Halldorsson TI, Thorsdottir I. Animal protein intake at 12 months is associated with growth factors at the age of six. Acta Paediatr 2014 May;103(5):512-517. [doi: 10.1111/apa.12576] [Medline: 24471761]

11. Braun KV, Erler NS, Kiefte-de Jong JC, Jaddoe VW, van den Hooven EH, Franco OH, et al. Dietary Intake of Protein in Early Childhood Is Associated with Growth Trajectories between 1 and 9 Years of Age. J Nutr 2016 Nov;146(11):2361-2367. [doi: 10.3945/jn.116.237164] [Medline: 27733529]

12. Hoppe C, Udam TR, Lauritzen L, Mølgaard C, Juul A, Michaelsen KF. Animal protein intake, serum insulin-like growth factor I, and growth in healthy 2.5-y-old Danish children. Am J Clin Nutr 2004 Aug;80(2):447-452. [doi: 10.1093/ajcn/80.2.447] [Medline: 15277169 ]

13. Voortman T, Braun KVE, Kiefte-de Jong JC, Jaddoe VWV, Franco OH, van den Hooven EH. Protein intake in early childhood and body composition at the age of 6 years: The Generation R Study. Int J Obes (Lond) 2016 Jun;40(6):1018-1025. [doi: 10.1038/ijo.2016.29] [Medline: 26975442]

14. Semba RD, Shardell M, Sakr Ashour FA, Moaddel R, Trehan I, Maleta KM, et al. Child Stunting is Associated with Low Circulating Essential Amino Acids. EBioMedicine 2016 Apr;6:246-252 [FREE Full text] [doi: 10.1016/j.ebiom.2016.02.030] [Medline: 27211567]

15. Socha P, Grote V, Gruszfeld D, Janas R, Demmelmair H, Closa-Monasterolo R, European Childhood Obesity Trial Study Group. Milk protein intake, the metabolic-endocrine response, and growth in infancy: data from a randomized clinical trial. Am J Clin Nutr 2011 Dec;94(6 Suppl):1776S-1784S [FREE Full text] [doi: 10.3945/ajcn.110.000596] [Medline: 21849603]

16. Melnik BC. Milk--A Nutrient System of Mammalian Evolution Promoting mTORC1-Dependent Translation. Int J Mol Sci 2015 Jul 27;16(8):17048-17087 [FREE Full text] [doi: 10.3390/ijms 160817048] [Medline: 26225961] 
17. Chavasit V, Kasemsup V, Tontisirin K. Thailand conquered under-nutrition very successfully but has not slowed obesity. Obes Rev 2013 Nov;14 Suppl 2:96-105 [FREE Full text] [doi: 10.1111/obr.12091] [Medline: 24102927]

18. Mo-suwan L, Aekplakorn W. Nutritional status of Thai children. In: Aekplakorn W, editor. Fifth Thai National Health Examination Survey (NHES). Bangkok: Health Systems Research Institute; 2014:121-146.

19. Rojroongwasinkul N, Kijboonchoo K, Wimonpeerapattana W, Purttiponthanee S, Yamborisut U, Boonpraderm A, et al. SEANUTS: the nutritional status and dietary intakes of 0.5-12-year-old Thai children. Br J Nutr 2013 Sep;110 Suppl 3:S36-S44 [FREE Full text] [doi: 10.1017/S0007114513002110] [Medline: 24016765]

20. Bureau of Nutrition, Ministry of Public Health. Dietary recommended intake for Thais 2020. Bangkok: AV Progressive Ltd; Mar 2020:117.

21. EFSA Panel on Dietetic Products, Nutrition and Allergies (NDA). Scientific Opinion on the appropriate age for introduction of complementary feeding of infants. EFSA Journal 2009 Dec 21;7(12):1423 [FREE Full text] [doi: 10.2903/j.efsa.2009.1423]

22. Fewtrell M, Bronsky J, Campoy C, Domellöf M, Embleton N, Fidler Mis N, et al. Complementary Feeding: A Position Paper by the European Society for Paediatric Gastroenterology, Hepatology, and Nutrition (ESPGHAN) Committee on Nutrition. J Pediatr Gastroenterol Nutr 2017 Jan;64(1):119-132 [FREE Full text] [doi: 10.1097/MPG.0000000000001454] [Medline: 28027215]

23. World Health Organization. WHO child growth standards: length/height-for-age, weight-for-age, weight-for-length, weight-for- height and body mass index-for-age: methods and development. Geneva: World Health Organization; 2006. URL: https://www.who.int/childgrowth/standards/technical report/en/ [accessed 2019-12-01]

24. de Onis M, Lobstein T. Defining obesity risk status in the general childhood population: which cut-offs should we use? Int J Pediatr Obes 2010 Dec;5(6):458-460. [doi: 10.3109/17477161003615583] [Medline: 20233144]

25. World Health Organization. Iron deficiency anaemia assessment, prevention, and control: A guide for programme managers. Geneva: World Health Organization; 2001. URL: https://www.who.int/nutrition/publications/micronutrients/ anaemia iron deficiency/WHO NHD 01.3/en/ [accessed 2019-12-01]

26. Institute of Nutrition, Mahidol University. In: Keeratichamroen A, editor. Manual of INMUCAL-Nutrients V. 4.0 Program. 1st ed. Nakhon Pathom: Metta Copy Print Ltd; 2018.

27. Lanigan JA, Wells JC, Lawson MS, Lucas A. Validation of food diary method for assessment of dietary energy and macronutrient intake in infants and children aged 6-24 months. Eur J Clin Nutr 2001 Feb;55(2):124-129 [FREE Full text] [doi: 10.1038/sj.ejcn.1601128] [Medline: 11305625 ]

28. Olaya GA, Lawson M, Fewtrell M. Iron Status at Age 6 Months in Colombian Infants Exclusively Breast-fed for 4 to 5 Versus 6 Months. J Pediatr Gastroenterol Nutr 2017 Mar;64(3):465-471 [FREE Full text] [doi: 10.1097/MPG.0000000000001301] [Medline: 27467112]

29. World Health Organization. The WHO Anthro for personal computer version 3.2.2: Software for assessing growth and development of the world's children. 2011. URL: https://www.who.int/childgrowth/software/en/

30. Roy SM, Spivack JG, Faith MS, Chesi A, Mitchell JA, Kelly A, et al. Infant BMI or Weight-for-Length and Obesity Risk in Early Childhood. Pediatrics 2016 May;137(5) [FREE Full text] [doi: 10.1542/peds.2015-3492] [Medline: 27244803]

31. Food consumption data of Thailand. Bangkok: National Bureau of Agricultural Commodity Food Standards (ACFS); 2016.

32. Llewellyn CH, van Jaarsveld CHM, Johnson L, Carnell S, Wardle J. Development and factor structure of the Baby Eating Behaviour Questionnaire in the Gemini birth cohort. Appetite 2011 Oct;57(2):388-396 [FREE Full text] [doi: 10.1016/j.appet.2011.05.324] [Medline: 21672566]

33. Textor J, van der Zander B, Gilthorpe MS, Liskiewicz M, Ellison GT. Robust causal inference using directed acyclic graphs: the R package 'dagitty'. Int J Epidemiol 2016 Dec 01;45(6):1887-1894 [FREE Full text] [doi: 10.1093/ije/dyw341] [Medline: 28089956]

34. Osmond C, Fall CHD. Conditional growth models: an exposition and some extensions. In: Rao ASRS, Saumyadipta P, Rao CR, editors. Handbook of statistics volume 37: disease modelling public health, part B. 1st edtion. Oxford: Elsevier; 2017:275-300.

35. Ngamjarus C. n4Studies: Sample Size Calculation for an Epidemiological Study on a Smart Device. Siriraj Med J 2016;68(3):160-170 [FREE Full text]

36. Olaya GA, Lawson M, Fewtrell MS. Efficacy and safety of new complementary feeding guidelines with an emphasis on red meat consumption: a randomized trial in Bogota, Colombia. Am J Clin Nutr 2013 Oct;98(4):983-993 [FREE Full text] [doi: 10.3945/ajcn.112.053595] [Medline: 23945724]

37. Winichagoon P. Thailand nutrition in transition: situation and challenges of maternal and child nutrition. Asia Pac J Clin Nutr 2013;22(1):6-15 [FREE Full text] [doi: 10.6133/apjen.2013.22.1.17] [Medline: 23353605]

38. Thailand National Health Security Office. Maternal-child health and the Universal health coverage scheme. 2018. URL: http://stream.nhso.go.th/wp-content/uploads/2018/09/final-OK4.pdf [accessed 2020-01-09]

39. Kittisakmontri K, Fewtrell M, Roekworachai K, Phanpong C, Lanigan J. Complementary feeding: Attitudes, knowledge and practices of urban families in northern Thailand. Nutr Diet 2019 Feb;76(1):57-66. [doi: 10.1111/1747-0080.12474] [Medline: $\underline{30216613}$ ] 


\begin{abstract}
Abbreviations
BMIZ: body mass index z-score

CBC: complete blood count

DBM: double burden of malnutrition

ESR: erythrocyte sediment rate

IGF-1: insulin-like growth factor I

IGFBP-3: insulin-like growth factor-binding protein III

LAZ: length-for-age z-score

WAZ: weight-for-age z-score

WLZ: weight-for-length z-score
\end{abstract}

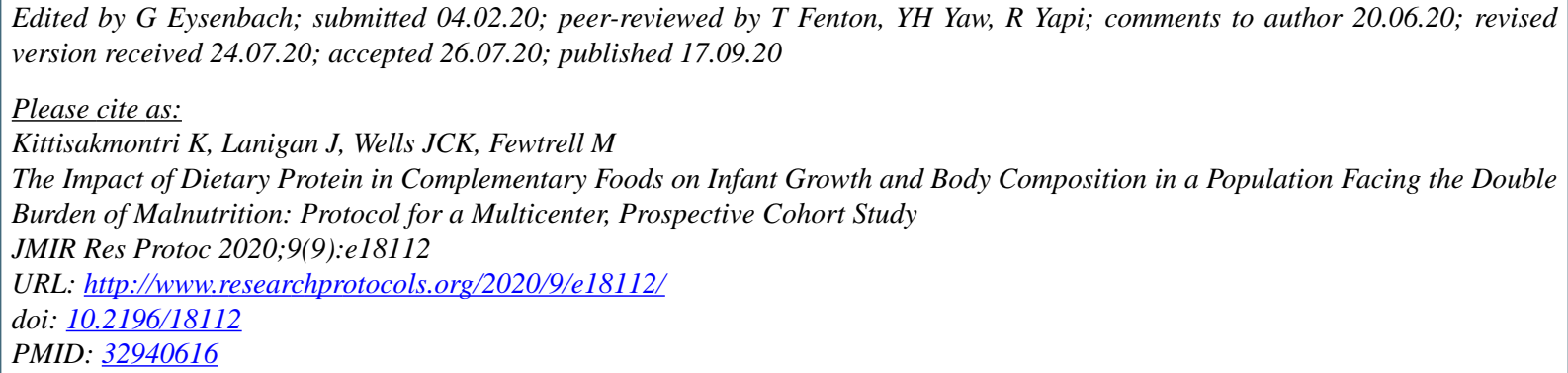

CKulnipa Kittisakmontri, Julie Lanigan, Jonathan C K Wells, Mary Fewtrell. Originally published in JMIR Research Protocols (http://www.researchprotocols.org), 17.09.2020. This is an open-access article distributed under the terms of the Creative Commons Attribution License (https://creativecommons.org/licenses/by/4.0/), which permits unrestricted use, distribution, and reproduction in any medium, provided the original work, first published in JMIR Research Protocols, is properly cited. The complete bibliographic information, a link to the original publication on http://www.researchprotocols.org, as well as this copyright and license information must be included. 